\title{
Candle in the wind
}

\author{
Empiirinen tutkimus nimien muistettavuudesta \\ virtuaalisessa minigolfpelissä
}

\section{Johdanto}

Erisnimet ovat taloudellinen viestinnän keino. Niiden avulla voidaan viitata yhteen tiettyyn kohteeseen lyhyesti ja yksinkertaisesti mutta silti selkeästi ja ymmärrettävästi. On huomattavasti helpompaa ja käytännöllisempää sanoa "Jonne Virtanen" kuin "se lähistöllä asuva teinipoika, joka jatkuvasti juo energiajuomia ja päristelee mopollaan pitkin kyliä". Nimen käyttö keskustelussa kuitenkin edellyttää, että puhuja muistaa nimen ja kuulija tunnistaa sen sisältämän viittauksen. Mikäli näin ei ole, joudutaan turvautumaan edellä esitetyn kaltaisiin pidempiin, kuvaileviin ilmauksiin. (Ks. myös Ainiala-Saarelma-Sjöblom 2008, 17.)

Aiemmissa tutkimuksissa on havaittu, että nimien muistaminen on selvästi vaikeampaa kuin appellatiivisten sanojen tai biografisen informaation. On esimerkiksi helpompaa muistaa, että henkilön ammatti on leipuri (engl. baker) kuin että tämän sukunimi on Baker (McWeeny ym. 1987). Toistaiseksi on epäselvää, mistä nimien muistamisen vaikeus johtuu, mutta mahdollisia selityksiä on esitetty useita: nimiä käytetään muuta sanastoa harvemmin, niitä ei voi korvata samankaltaisilla synonyymeillä eivätkä ne useinkaan kuvaile viittauskohteensa ominaisuuksia (Brédart 2016, 482-487). Asiaan saattaa vaikuttaa myös, että ihmisen on havaittu käsittelevän nimiä eri aivoalueella kuin muuta sanastoa (Müller 2010).

Koska nimien muistaminen on tärkeää mutta vaikeaa, lienee luontevaa ajatella, että se olisi yksi nimistöntutkimuksen keskeisistä tutkimusaiheista. Tähänastisissa tutkimuksissa aihe on kuitenkin ollut varsin vähän esillä. Esimerkiksi onomastiikan merkittävimmissä käsikirjoissa sitä käsitellään melko lyhyesti ja kapea-alaisesti (Wippich 1995; Brédart 2016). Yleisemmistä tutkimussuuntauksista aiheeseen liittyvät lähimmin ns. nimikompetenssitutkimukset, joissa selvitellään, kuinka hyvin henkilöt tuntevat asuinympäristönsä paikannimiä (ks. Ainiala 2016a, 374-377). Nimikompetenssiin vaikuttavat kuitenkin muistin ohella useat muut tekijät, joten näiden tutkimusten tuloksista ei voi vetää suoria johtopäätöksiä nimien muistamiseen. 
Laajemmin nimien muistamista on tutkittu kognitiivisen psykologian näkökulmasta. Näitä tutkimuksia vetävät yhteen mm. Gillian Cohen ja Deborah Burke (1993), Richard Hanley ja Cohen (2008) sekä Bennett Schwartz (2014). Tutkimukset ovat valtaosin keskittyneet henkilönnimien muistamiseen, joskin myös joitakin kaupallista nimistöä (Ahn-La Ferle 2008; Luna-Carnevale-Lerman 2013) ja paikannimiä (Kalakoski-Saariluoma 2001) käsitteleviä tutkimuksia on tehty. Näiden tutkimusten fokus on kuitenkin ollut pääasiassa siinä, kuinka hyvin erilaiset ihmisyksilöt ja -ryhmät muistavat nimiä. Vähemmälle huomiolle on jäänyt nimien muistettavuus eli se, kuinka hyvin mikäkin nimi muistetaan ja mitkä tekijät muistamiseen vaikuttavat. Muistettavuutta sivutaan lyhyesti muutamissa tutkimuksissa (yhteenveto näistä ks. Hanley-Cohen 2008, 132-133), mutta pääasiallisena tarkastelukohteena se on ainoastaan Tina Lowreyn, L. J. Shrumin ja Tony Dubitskyn (2003) artikkelissa.

Nimien muistettavuuden jättäminen vähälle huomiolle on nähdäkseni merkittävä puute aiemmissa tutkimuksissa. Jo arkikokemuksen perusteella lienee selvää, että toiset nimet muistetaan toisia paremmin, vaikka niiden viittauskohteet olisivat keskenään jokseenkin samankaltaiset ja yhtä tärkeät. Moni suomalainen esimerkiksi muistanee, että Perun pääkaupunki on Lima, mutta kuinka moni muistaa Perun naapurimaan, Ecuadorin, pääkaupungin nimen? Eroa selittänee lähinnä se, että lima sattuu olemaan suomen kielen sana. Mikäli tiedettäisiin tarkemmin, millaiset tekijät nimen muistettavuuteen vaikuttavat, voisivat tulevaisuuden nimenantajat ottaa tämän huomioon ja luoda helpommin muistettavia nimiä (ks. myös Usunier-Shaner 2002).

Tässä artikkelissa tarkastelen nimien muistettavuutta empiirisen muistikoeaineiston pohjalta. Olen kerännyt aineiston suomalaisessa verkkopeliyhteisö Aapelissa sijaitsevan Minigolf-nimisen pelin pelaajayhteisön avulla. Esittelen Aapelia, Minigolfia ja Minigolfin radannimiä luvussa 2 ja muistikokeiden toteutusta luvussa 3. Tämän jälkeen analysoin kokeiden tuloksia, luvussa 4 kvalitatiivisesti ja luvussa 5 kvantitatiivisesti. Luvussa 6 vedän yhteen tutkimuksen keskeisimmän annin.

\section{Aapeli, Minigolf ja radannimet}

Olen käsitellyt Aapelia, Minigolfia ja Minigolfin radannimiä myös useissa aiemmissa kirjoituksissani (erityisesti Hämäläinen 2017; 2018; ks. myös Hämäläinen 2016a; 2016b), joten tyydyn tässä yhteydessä tekemään tiivistetyn yleiskatsauksen näihin aiheisiin.

Aapeli (www.aapeli.com) on suomalaisen Apaja Creative Solutions Oy:n vuonna 2002 perustama verkkopelisivusto. Se sisältää noin 50 erilaista verkkopeliä, jotka ovat pääosin suhteellisen yksinkertaisia ja ajalliselta kestoltaan lyhyitä. Sivusto on suomalaisella mittapuulla varsin menestynyt: sinne on rekisteröity 15 vuoden aikana yli 5 miljoonaa käyttäjätiliä. Sen suurimmat suosion vuodet ajoittuvat vuosiin 2005-2010, jolloin se tavoitti parhaimmillaan viikoittain yli 100 ooo suomalaista. Näihin aikoihin sille perustettiin myös useita vieraskielisiä tytärsivustoja, jotka tunnetaan nimellä Playforia. Nykyisin noin 60 prosenttia käyttäjistä on ulkomaalaisia. (Hämäläinen 2017, 50.) 
Minigolf (Aapeli 2002) on yksi Aapelin vanhimmista ja suosituimmista peleistä. Sen perusidea on sama kuin reaalimaailman minigolfissa: saada pallo lähtöpaikasta erilaisten esteiden ohi reikään mahdollisimman vähin lyönnein. Aapelin Minigolfissa radat ovat kuitenkin keskimäärin selvästi pidempiä ja monimutkaisempia kuin reaalimaailmassa. Peli myös sisältää useita elementtejä, joita reaalimaailman minigolfissa ei ole, kuten mutaa, jäätä, suota, magneetteja ja maamiinoja. Peliä voi pelata yksin tai reaaliaikaisesti sivuston muita käyttäjiä vastaan. Minigolfiin voi tutustua tarkemmin koostamani esittelyvideon (Hämäläinen 2016c) avulla.

Minigolfin ympärillä on pelin julkaisemisesta lähtien toiminut pienehkö mutta tiivis aktiivisten harrastajien yhteisö (Hämäläinen 2017). Siihen kuuluu laskutavasta riippuen 30-100 jäsentä. Yksi keskeinen osa yhteisön toimintaa ovat verkkokeskustelut jäsenten välillä. Näissä keskusteluissa jaetaan kokemuksia pelitapahtumista ja pohditaan mahdollisia parannuksia ratojen ennätystuloksiin. Koska pelin radat ovat hyvinkin erilaisia, on tärkeää kontekstualisoida nämä tapahtumat ja pohdinnat. Tämä tapahtuu radannimien avulla. Yhteisön jäsenet eivät kuitenkaan muista kaikkia radannimiä, mikä aiheuttaa ongelmia keskustelujen etenemisessä, kuten yhteisön IRC-keskusteluista poimitut esimerkit 1 ja 2 osoittavat. Mikäli kertoja ei muista radannimeä, kuten esimerkissä 1 , ei hänen kertomuksellaan ole juurikaan informaatioarvoa. Mikäli taas vastaanottaja ei muista nimeä (Blue Screen), kuten esimerkissä 2, joudutaan häntä auttamaan radan ominaisuuksia kuvailemalla (uus; lukee että error; Darwinin 2012). Tämä keskeytys saattaa ohjata keskustelun sivuun alkuperäisestä aiheesta.

(1) $<$ Koopa $>$ jes vedin jonku radan 3

$<$ Koopa $>$ en muista nimee

(2) <stradlin> meneekös blue screen muuten 3

$<$ adi_MiE > järkyttävää

$<$ adi_MiE $>$ en muista rataa

$<$ stradlin $>$ uus

$<$ stradlin $>$ lukee että error

$<$ adi_MiE $>$ eikun joo reps

$<$ ses $>$ darwinin 2012

Minigolfissa on kaikkiaan 2072 rataa, ja jokaisella radalla on nimi. Nimi on pelatessa koko ajan näkyvillä pelialueen alapuolella (kuva 1). Nimen radalle antaa sen suunnittelija eli ns. ratamestari. Valtaosa radannimistä, 84 prosenttia, on englanninkielisiä. Muunkielisiä useimmiten suomea, latinaa, italiaa, ranskaa tai saksaa - on 5 prosenttia ja 3 prosenttia internationalismeja eli ilmauksia, jotka esiintyvät jokseenkin samanlaisina useissa eri kielissä ja joita siksi on vaikeaa luokitella miksikään tietyksi kieleksi (mm. Enigma, Inferno, OK, Safari, Sonata). Loput 8 prosenttia ovat tekosanoja eli eivät edusta mitään tunnettua kieltä. ${ }^{1}$

1 Olen lainannut termit internationalismi ja tekosana Paula Sjöblomin (2006) suomalaisia yritysnimiä käsittelevästä tutkimuksesta. 


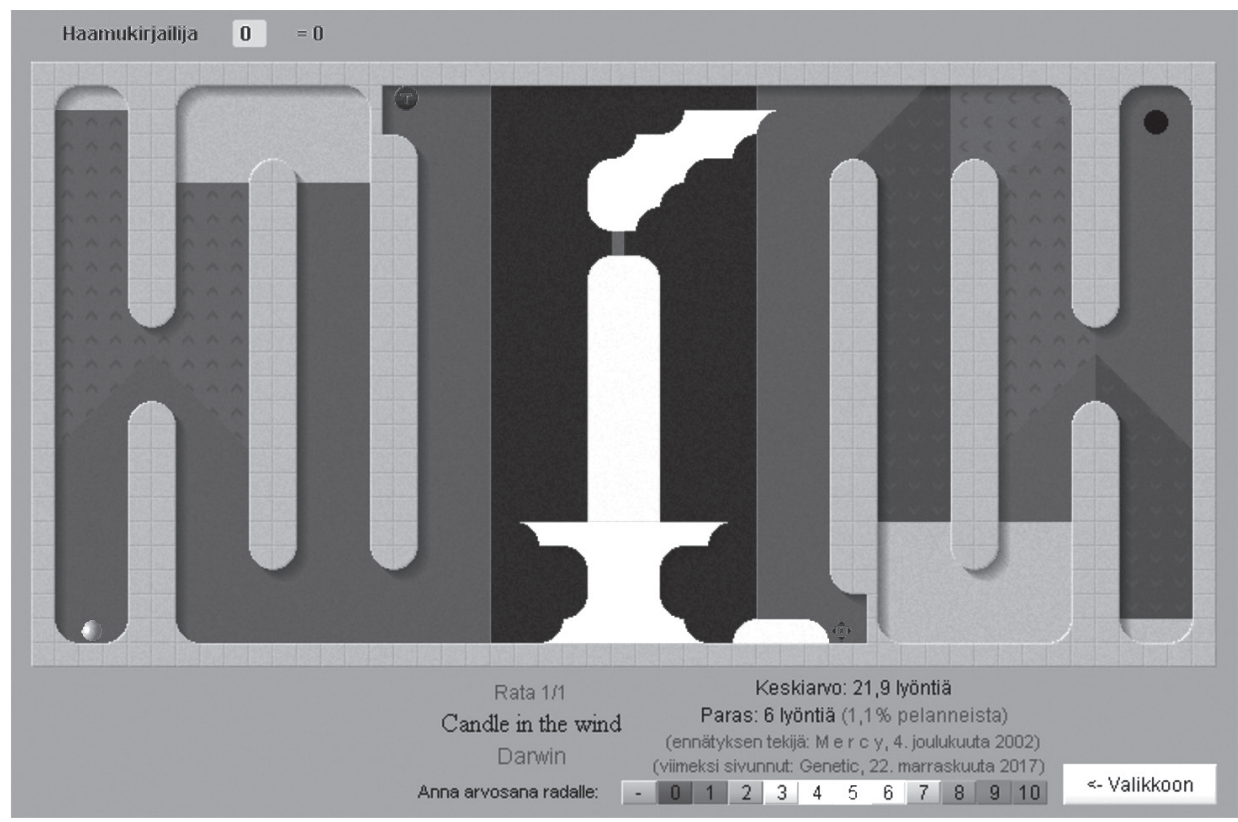

Kuva 1. Näkymä Minigolfin peli-ikkunasta. Radan nimi (Candle in the wind) alhaalla keskellä.

Radannimet Minigolfissa ovat uniikkeja, eli pelissä ei ole kahta täysin samanlaista nimeä. Sen sijaan keskeinen osa nimisysteemin rakennetta ovat ratasarjat eli sellaiset kahden tai useamman radan ryhmät, jotka on nimetty yhtenevällä tavalla ja jotka usein ovat myös saman ratamestarin ajallisesti lähekkäin tekemiä sekä pelillisesti tai ulkoasultaan samankaltaisia. Sarjan radat nimetään useimmiten juoksevan numeroinnin avulla (Zab 1 - Zab 2 - Zab 3; Swinging - Swinging II - Swinging III), mutta osat voidaan erottaa toisistaan myös lisäämällä tai vaihtamalla jokin nimielementti (Water Par Four - Water Par Four Edit; Dream of Four Strokes - Dream of Six Strokes - Dream of Ten Strokes). Sarjat koostuvat useimmiten kahdesta tai kolmesta mutta enimmillään jopa 10 radasta. 27 prosenttia Minigolfin radoista kuuluu johonkin ratasarjaan.

Nimenantoperusteidensa mukaan radannimet voidaan jakaa neljään päluokkaan: (1) radan rakennuselementteihin, (2) muotoihin tai (3) pelaamiseen liittyviin sekä (4) radan ominaisuuksiin liittymättömiin nimiin. Radan elementteihin liittyy 23 \% nimistä, $\mathrm{mm}$. First water then acid, Icy hill ja Water corners. ${ }^{2}$ Radassa esiintyvään muotoon liittyy 24 \% nimistä, mm. KSM, Pull the Anchor Up! ja Pyramid. Radan pelaamiseen liittyy 36 \% nimistä, mm. Dream of Four Strokes, Easy job ja Try once. 29 \% nimistä ei liity millään

2 Kaikki tässä kappaleessa mainitut radannimet esiintyvät muistikokeissa. Kuvat radoista ovat nähtävissä liitteessä 1 . 
havaittavalla tavalla radan ominaisuuksiin. Tähän ryhmään kuuluu ns. nimikkoratoja eli yhteisössä arvostetun pelaajan tai ratamestarin mukaan nimettyjä ratoja (esim. Moetikoitsijae, Star paw), viittauksia populaarikulttuuriin (esim. Easy for MacGyver, ice ice baby) sekä ratamestarien itse keksimiä tekosanoja (esim. Eone, Fivagon, Siwali, Zolo). Nimi voi kuulua samanaikaisesti useampaan kuin yhteen mainituista pääluokista. Esimerkiksi ice ice baby liittyy samanaikaisesti rataelementtiin (jää) sekä populaarikulttuuriin (rap-artisti Vanilla Icen kappale). Tämän vuoksi luokkien summa (112 \%) ylittää $100 \%$.

Tutkimuksen aineistolähde on suomalaisen nimistöntutkimuksen kontekstissa varsin poikkeuksellinen. Pääasiallinen peruste sen valinnalle on oma läheinen ja pitkäaikainen suhteeni Minigolfiin. Olen harrastanut peliä vuodesta 2005 lähtien ja ollut etenkin 2010-luvulla aktiivisesti mukana pelaajayhteisön toiminnassa. Pitkä kokemus pelistä ja pelaajayhteisön kulttuurista on auttanut minua useissa tutkimuksen vaiheissa, muun muassa koehenkilöiden etsimisessä sekä radannimien ja koetulosten analysoinnissa. Nimen muistettavuuteen vaikuttavat muutkin tekijät kuin itse nimen ominaisuudet, kuten kohteen tärkeys ja kiinnostavuus kontekstissaan. Kontekstin ymmärtäminen onkin tällaisen tutkimuksen toteuttamisen kannalta erittäin tärkeää.

\section{Muistikokeet}

Aineistoni koostuu kahdesta asetelmaltaan päinvastaisesta muistikokeesta. Viittaan niihin jatkossa ilmauksilla koe 1 ja koe 2. Kokeessa 1 osallistujille näytettiin 50 kuvaa Minigolfin radoista, ja heidän tehtävänään oli pyrkiä muistamaan kunkin radan nimi. Kokeessa 2 osallistujille puolestaan näytettiin 50 Minigolfin radannimeä, ja heidän tehtävänään oli vapaamuotoisesti kuvailla kunkin radan ominaisuuksia. Molemmissa kokeissa kaikille osallistujille näytettiin samat 50 kuvaa tai nimeä samassa järjestyksessä. Kyseiset radat valittiin arpomalla kaikkien Minigolfin ratojen joukosta ${ }^{3}$.

Kokeeseen 1 osallistui 26, kokeeseen 2 puolestaan 20 henkilöä. 13 henkilöä osallistui molempiin kokeisiin, joten kaikkiaan kokeisiin osallistui 33 eri henkilöä. Heistä 31 on äidinkieleltään suomenkielisiä, yksi saksankielinen ja yksi turkinkielinen. Kaikki osallistujat ovat miehiä, iältään 18-40-vuotiaita, mikä vastaa aktiivipelaajien yhteisön demografista profiilia. Osallistujat ovat Minigolfin aktiivisia ja pitkäaikaisia harrastajia sekä pelaajayhteisön jäseniä. He ovat pelatessaan nähneet kokeissa esiintyvät radat nimineen useita kertoja, joten mahdollinen nimien osaamattomuus kokeissa todellakin johtuu siitä, että nimiä ei muisteta, eikä siitä, että nimiä ei tiedetä.

Kokeiden välillä oli pitkähkö aika: koe 1 toteutettiin heinäkuussa 2014 ja koe 2 marraskuussa 2015. Tämän vuoksi en usko, että kokeeseen 1 osallistuminen on vaikuttanut kokeen 2 tuloksiin, vaikka osa koehenkilöistä olikin samoja. Molemmat kokeet suoritettiin

3 Otosta ei ole balansoitu siten, että se sisältäisi tietyn määrän tiettyjä ominaisuuksia edustavia ratoja. En halunnut ennakkoon olettaa, millaiset muuttujat saattaisivat vaikuttaa muistettavuuteen. 
verkon välityksellä, koe 1 sähköisen kyselylomakkeen ${ }^{4}$ avulla ja koe 2 IRC-yksityiskeskustelussa minun ja osallistujan välillä. Fyysisen valvonnan puute toki jätti koehenkilöille mahdollisuuden yrittää huijata vastaamisessa erilaisten kuva-aineistojen, kuten Minigolfin ratalistan (Taateli.com 2018) avulla. Koetuloksissa ei kuitenkaan näy merkkejä huijaamisesta, eikä siihen nähdäkseni ollut syytäkään, sillä en julkaise tuloksia yksittäisten koehenkilöiden menestyksestä.

Kummassakin kokeessa vastauskentät olivat avoimia, joten vastauksissa on runsaasti vaihtelua. Tämä tekee niiden arvioimisesta haastavaa. Yksinkertainen jako oikeisiin ja vääriin vastauksiin jättäisi paljon informaatiota huomioimatta, sillä osa vastauksista ei ole täsmälleen oikein mutta lähellä oikeaa. Aidossa keskustelutilanteessa jo tällainen lähelle oikeaa osuva nimi saattaa riittää viittauksen tunnistamiseen. Toisaalta oikea nimi lienee lähes oikeaa nimeä helpompi ymmärtää ja siten paras vaihtoehto. Siksi olen päätynyt jakamaan vastaukset kolmeen ryhmään: oikein (2 pistettä), osittain oikein (1p) sekä väärin (op). Väärin-kategoriaan olen sisällyttänyt myös ne varsin runsaslukuiset tietueet, joissa koehenkilö ei ole vastannut mitään.

Olen koonnut alle joitakin esimerkkejä kokeen 1 vastausten pisteytyksestä ratojen Beach Mission: Acid Factory ja Hollowalls II kohdalla. Kuten esimerkeistä 3 ja 4 havaitaan, olen antanut 2 pistettä myös joistakin hyvin pieniä virheitä sisältävistä vastauksista (Beach Mission I - Acid Factory; Hollowwalls II), mikäli olen tulkinnut, että nämä virheet eivät olennaisesti häiritsisi nimen ymmärrettävyyttä aidossa keskustelutilanteessa. Vastauksista, joissa ratasarjan numero on väärä tai puuttuu (Hollowalls IV ja Hollowalls), olen antanut 1 pisteen. Muutamissa tapauksissa olen tulkinnut vastauksen vääräksi, vaikka se sisältäisikin jonkin oikean nimielementin (Acid Castle, On the Beach). Nähdäkseni näin kauas oikeasta nimestä jäävää viittausta olisi lähes mahdotonta ymmärtää aidossa keskustelutilanteessa.

(3) Beach Mission: Acid Factory

Beach Mission I - Acid Factory (2p)

Acid Factory (1p)

Acid Beach Mission (1p)

Acid Castle (op)

On the Beach (op)

(4) Hollowalls II

Hollowwalls II (2p)

Hollowalls IV (1p)

Hollowalls (1p)

4 Lomake on nähtävissä osoitteessa www.elomake.helsinki.fi/lomakkeet/52113 (viitattu 21.5.2018). Vastaajille antamani ohjeistus taas on tutkimusta varten perustamassani foorumiavauksessa osoitteessa www.aapeli.com/community/forums/topic/186190 (viitattu 21.5.2018). 


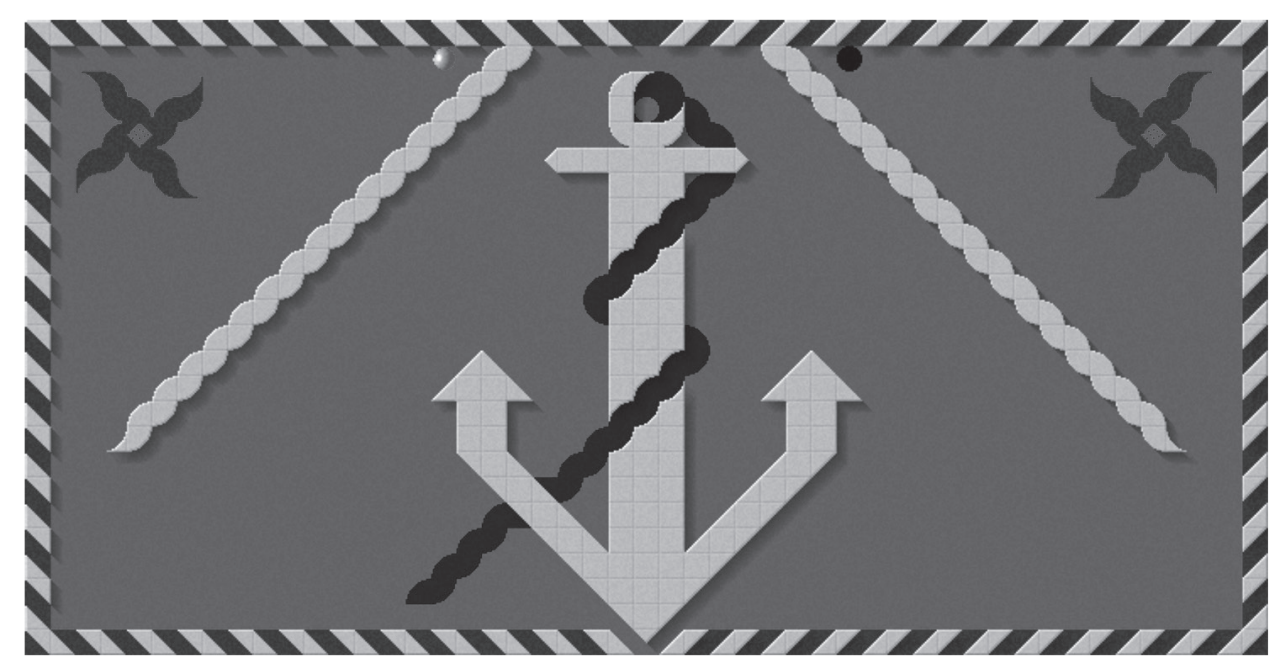

Kuva 2. Pull the anchor up!

Kokeessa 2, jossa koehenkilöt saivat kuvailla ratoja vapaamuotoisesti, vastausten kirjo on vielä suurempi. Koehenkilöt ovat voineet kertoa esimerkiksi, kuka radan on suunnitellut, milloin se on julkaistu, mikä on radan ennätystulos ja kuka sitä pitää hallussaan, tai millaisia elementtejä ja muotoja rata sisältää. Ohjeistin koehenkilöitä kuitenkin vastaamaan suhteellisen lyhyesti, jotta kokeesta ei tulisi heille liian työlästä. Yleensä olen tulkinnut riittäväksi vastaukseksi kolmen ominaisuuden mainitsemisen. Esimerkiksi radan Pull the anchor up! (kuva 2) kohdalla olen arvioinut vastauksia seuraavasti:

(5) contrickin tekemä / oli aikoinaan tumego:n uniikki / kolmen lyönnin rata jossa yritetään nimensä mukaisesta kuvastaa ankkurin muotoa / ankkurin voi joko kiertää ylhäältä tai mennä läpi hiekan päältä, ahtaasta kolosta / perusrata, joka voi käydä hermoille $(2 \mathrm{p})^{5}$

(6) 3 lyönnin con-trickin / tumen ennätys / reunat seinä, vesi viistoraitoja (2p)

(7) taiderata, keskellä ankkuri / hiekkaa ja vettä jonkun verran (1p)

(8) kolme lyöntiä. paljo vettä (1p)

5 Osa koehenkilöistä antoi vastauksensa useassa osassa, rivinvaihtonäppäintä käyttäen. Tilan säästämiseksi olen korvannut rivinvaihdon /-merkillä. 


\section{Muistikokeiden tulokset}

Tässä luvussa esittelen muistikokeiden tulokset sekä laadullisia havaintoja niistä. Kaikkien kokeissa esiintyneiden nimien läpikäyminen on tässä yhteydessä mahdotonta, joten tyydyn poimimaan tuloksista edustavimpina ja kiinnostavimpina pitämiäni esimerkkejä. Aiheesta tarkemmin kiinnostuneet voivat lukea myös liitteen 1, joka sisältää kommentit kustakin nimestä.

Koetulokset on koottu taulukoihin 1 ja 2, joissa nimet ovat saamiensa yhteispisteiden mukaisessa järjestyksessä. On syytä huomata, että vaikka pistemäärä kuvaa nimen menestystä kokeessa varsin hyvin, ei se ole aivan täsmällinen mittari. Vaikka olen antanut luokille "oikein", "osittain oikein" ja "väärin" numeeriset arvot, ovat ne todellisuudessa nominaalisia. Ei siis voida yksiselitteisesti todeta, ovatko neljä oikeaa vastausta ja kahdeksan osittain oikeaa vastausta yhtä hyviä tuloksia keskenään, vai onko jompikumpi niistä parempi.

Minigolfin radannimien muistaminen ei ole pelin aktiivisille harrastajillekaan helppoa. Kokeen 1 kaikkiaan 1300 vastauksesta olen tulkinnut oikeiksi 285 (21,9\%), osittain oikeiksi $133(10,2 \%)$ ja vääriksi $882(67,8 \%)$. Kokeen 2 kaikkiaan 1 ooo vastauksesta olen puolestaan tulkinnut oikeiksi 250 (25,0 \%), osittain oikeiksi 91 (9,1\%) ja vääriksi 659 $(65,9 \%)$. Nimien välillä esiintyy kummassakin kokeessa suuria eroja. Jotkin nimet on muistanut enemmistö vastaajista, joitakin taas ei yksikään vastaaja.

\subsection{Koe 1}

Kokeen 1 (taulukko 1) selvästi parhaiten muistettu nimi on Candle in the wind (kuva 1). Nimi viittaa sekä radan keskellä sijaitsevaan suureen kynttilän muotoiseen figuuriin että Elton Johnin samannimiseen kappaleeseen. Molemmat nimeämisperusteet näyttävät selvästi auttavan nimen muistamista. Myös muut populaarikulttuuriin liittyvät nimet (ice ice baby; Squary Movie 1; Easy for MacGyver; Run Forrest, Run!') löytyvät taulukon yläpäästä. Radan muotoihin puolestaan kärkipään nimistä liittyvät myös Star paw, Squary Movie 1, Screwdriver \& screws sekä Ball road.

Myös yhteys radan pelaamiseen näyttää helpottavan nimen muistamista. Toiseksi muistetuin nimi on Narrow squeak - radassa edetään useita kapeita alamäkiputkia pitkin $^{7}$. Kolmanneksi muistetuin nimi Dream of Four Strokes puolestaan motivoituu siitä, että radan paras mahdollinen tulos on neljä lyöntiä, mutta sen saavuttaminen on vaikeaa. Myös toinen radan ihannetulokseen liittyvä nimi, Water Par Four, mahtuu kymmenen parhaiten muistetun nimen joukkoon. Sen sijaan nimet, joiden yhteys radan pelaamiseen on vähemmän ilmeinen, kuten Senoz, Hazardous, Meeting place ja Grand Slam II, löytyvät pääosin taulukon loppupäästä.

6 Nimet viittaavat rap-artisti Vanilla Icen kappaleeseen, Scary Movie -nimiseen kauhukomediaelokuvien sarjaan, tv-sarjaan Ihmemies MacGyver sekä elokuvaan Forrest Gump.

7 Idiomi narrow squeak voitaneen suomentaa 'nipin napin'. Kirjaimellisesti narrow kuitenkin tarkoittaa kapeaa tai ahdasta. 
Taulukot 1 ja 2. Kokeiden 1 (vasemmalla) ja 2 (oikealla) tulokset.

\begin{tabular}{|c|c|c|c|c|}
\hline Radan nimi & $2 p$ & $1 \mathrm{p}$ & op & Pist \\
\hline Candle in the wind & 19 & 3 & 4 & 41 \\
\hline Narrow Squeak & 15 & 2 & 9 & 32 \\
\hline Dream of Four Strokes & 12 & 4 & 10 & 28 \\
\hline ice ice baby & 12 & 2 & 12 & 26 \\
\hline Star paw & 12 & 2 & 12 & 26 \\
\hline Evac Enim & 10 & 3 & 13 & 23 \\
\hline Fortress-1 & 10 & 2 & 14 & 22 \\
\hline Squary Movie 1 & 9 & 4 & 13 & 22 \\
\hline Water Par Four & 7 & 8 & 11 & 22 \\
\hline Easy for MacGyver & 8 & 4 & 14 & 20 \\
\hline Screwdriver \& screws & 7 & 6 & 13 & 20 \\
\hline Beach mission: Acid factory & 6 & 7 & 13 & 19 \\
\hline Nab Geometry & 8 & 3 & 15 & 19 \\
\hline Ball road & 7 & 4 & 15 & 18 \\
\hline Hollowalls II & 4 & 10 & 12 & 18 \\
\hline Unreal Reality & 9 & 0 & 17 & 18 \\
\hline Diagonal boredom & 7 & 3 & 16 & 17 \\
\hline Magnet Cannon & 6 & 5 & 15 & 17 \\
\hline Small can be tricky III & 3 & 11 & 12 & 17 \\
\hline Captain of the bath tub & 6 & 4 & 16 & 16 \\
\hline Run Forrest, Run! & 8 & 0 & 18 & 16 \\
\hline Zolo & 8 & 0 & 18 & 16 \\
\hline Playcards & 6 & 2 & 18 & 14 \\
\hline "Hip hip hurray" & 6 & 1 & 19 & 13 \\
\hline Icy Shot II & 2 & 9 & 15 & 13 \\
\hline Retsetigub V & 2 & 9 & 15 & 13 \\
\hline Bob, Smile \& Murder Mary & 3 & 6 & 17 & 12 \\
\hline Helix & 6 & 0 & 20 & 12 \\
\hline Acid Twins & 4 & 3 & 19 & 11 \\
\hline Dangerous Accelerator & 4 & 2 & 20 & 10 \\
\hline Euphoric & 5 & 0 & 21 & 10 \\
\hline Hydrating effect & 5 & 0 & 21 & 10 \\
\hline Jigsaw & 5 & 0 & 21 & 10 \\
\hline Hitchhiker & 4 & 1 & 21 & 9 \\
\hline Calicula & 4 & 0 & 22 & 8 \\
\hline Sweep & 4 & 0 & 22 & 8 \\
\hline Terrace & 4 & 0 & 22 & 8 \\
\hline Yackety Yak & 4 & 0 & 22 & 8 \\
\hline Senoz & 3 & 1 & 22 & 7 \\
\hline WeeWoo & 3 & 1 & 22 & 7 \\
\hline Flush Brim & 3 & 0 & 23 & 6 \\
\hline Hazardous & 3 & 0 & 23 & 6 \\
\hline Icy hill & 2 & 2 & 22 & 6 \\
\hline Meeting place & 3 & 0 & 23 & 6 \\
\hline Micro & 3 & 0 & 23 & 6 \\
\hline No Comment & 3 & 0 & 23 & 6 \\
\hline Downhillargh & 2 & 1 & 23 & 5 \\
\hline Basic Z-4 & 1 & 2 & 23 & 4 \\
\hline Grand Slam II & 0 & 4 & 22 & 4 \\
\hline Fivagon & 0 & 0 & 26 & 0 \\
\hline
\end{tabular}

\begin{tabular}{|c|c|c|c|c|}
\hline Radan nimi & $2 p$ & $1 \mathrm{p}$ & op & Pist \\
\hline Acid Twins & 9 & 4 & 7 & 22 \\
\hline Hookup \& Siam & 10 & 2 & 8 & 22 \\
\hline KSM & 9 & 4 & 7 & 22 \\
\hline M-balls & 10 & 1 & 9 & 21 \\
\hline Pull the anchor up! & 9 & 3 & 8 & 21 \\
\hline Siwali & 9 & 3 & 8 & 21 \\
\hline Dance Sucker & 10 & 0 & 10 & 20 \\
\hline Hooked at the horn & 9 & 1 & 10 & 19 \\
\hline Stone Passage Race II & 8 & 3 & 9 & 19 \\
\hline Boring Mill & 9 & 0 & 11 & 18 \\
\hline Bunker of Death & 9 & 0 & 11 & 18 \\
\hline Moetikoeitsijae & 8 & 2 & 10 & 18 \\
\hline First water then acid & 8 & 1 & 11 & 17 \\
\hline Try once & 6 & 5 & 9 & 17 \\
\hline Just a Gigolo & 8 & 0 & 12 & 16 \\
\hline Typhus & 7 & 2 & 11 & 16 \\
\hline Da Bomb & 7 & 1 & 12 & 15 \\
\hline Halfed & 6 & 3 & 11 & 15 \\
\hline Estimation Quarter & 6 & 2 & 12 & 14 \\
\hline Tricky Trio & 5 & 4 & 11 & 14 \\
\hline Normal Battle & 6 & 1 & 13 & 13 \\
\hline Waveform & 4 & 5 & 11 & 13 \\
\hline Caverun & 5 & 2 & 13 & 12 \\
\hline Cucumber & 6 & 0 & 14 & 12 \\
\hline Sugar Hills & 6 & 0 & 14 & 12 \\
\hline Blue Moment & 4 & 3 & 13 & 11 \\
\hline Chains of misery & 4 & 3 & 13 & 11 \\
\hline Tower & 4 & 3 & 13 & 11 \\
\hline Round an' round & 5 & 0 & 15 & 10 \\
\hline Seven Holes & 5 & 0 & 15 & 10 \\
\hline Sideways & 2 & 5 & 13 & 9 \\
\hline A River Runs Through It & 3 & 2 & 15 & 8 \\
\hline Bouncy Rooms & 4 & 0 & 16 & 8 \\
\hline Eone & 3 & 2 & 15 & 8 \\
\hline On the bank & 4 & 0 & 16 & 8 \\
\hline Trick & 4 & 0 & 16 & 8 \\
\hline Water Monday & 3 & 1 & 16 & 7 \\
\hline Carol & 3 & 0 & 17 & 6 \\
\hline Easy job V & 2 & 2 & 16 & 6 \\
\hline Insomnia & 3 & 0 & 17 & 6 \\
\hline Pyramid & 2 & 2 & 16 & 6 \\
\hline Acid Ridge & 2 & 1 & 17 & 5 \\
\hline Minimalism I & 0 & 5 & 15 & 5 \\
\hline Tradcave II & 1 & 3 & 16 & 5 \\
\hline Beware water III & 0 & 4 & 16 & 4 \\
\hline Easy job & 0 & 4 & 16 & 4 \\
\hline Bendable & 1 & 1 & 18 & 3 \\
\hline Swinging III & 1 & 0 & 19 & 2 \\
\hline Upset & 1 & 0 & 19 & 2 \\
\hline Water corners & 0 & 0 & 20 & 0 \\
\hline
\end{tabular}


Ratasarjaan kuuluvien ratojen nimet keräsivät runsaasti osittain oikeita vastauksia. Sarjan nimen muistaminen oli yleistä, sarjanumeroiden taas harvinaista. Nimistä Icy Shot II ja Retsetigub $V$ ratasarjan nimen muisti 11 vastaajaa mutta heistä vain 2 muisti oikean sarjanumeron. Icy Shot -sarjaan kuuluu kolme ja Retsetigub-sarjaan viisi osaa, joten on mahdollista, että oikein vastanneetkin ovat pikemminkin arvanneet tai päätelleet kuin varsinaisesti muistaneet oikean numeron.

Ainoa nimi, jota yksikään koehenkilö ei muistanut, on Fivagon. Nimi on tekosana, jossa Fiv- saattaa liittyä radan viiteen huoneeseen ja -gon monikulmioihin. Tulkinta on kuitenkin epävarma ja edellyttää nimen alkuperän perusteellista analysoimista. Kokemukseni mukaan useimmat pelaajat eivät tätä harrasta, joten heille nimi näyttäytynee opaakkina. Myös kokeen 1 kolme muuta semanttisesti läpinäkymätöntä radannimeä (Calicula, WeeWoo ja Zolo) muistettiin suhteellisen heikosti. Kahdeksaa oikeaa vastausta nimeen Zolo voidaan pitää varsin pienenä määränä, sillä kyseessä on useiden pelaajien mielestä yksi Minigolfin legendaarisimmista radoista ${ }^{8}$.

Taulukon häntäpäästä löytyy myös useita nimiä, jotka sisältävät ymmärrettäviä englanninkielisiä ilmauksia mutta eivät liity radan ominaisuuksiin: Jigsaw'lehtisaha, palapeli'; Hitchhiker 'liftaaja'; Sweep 'lakaista, pyyhkäistä'; Micro 'pieni, miljoonasosa, mikroaaltouuni, mikrotietokone'; No Comment 'ei kommenttia'. Vaikuttaisi myös siltä, että harvemmin käytettyä englannin kielen sanastoa sisältävät nimet (mm. Flush Brim; Hydrating effect; Yackety Yak) on muistettu keskimäärin melko heikosti. Tämän voi tulkita johtuvan siitä, että osa koehenkilöistä ei tunne kyseisiä sanoja eikä näin ollen pysty ymmärtämään niiden mahdollista yhteyttä radan ominaisuuksiin.

\subsection{Koe 2}

Radan muotoihin liittyvät nimet on muistettu hyvin myös kokeessa 2 (taulukko 2). Kuudesta parhaiten muistetusta nimestä tällaisia on neljä: Acid Twins sisältää kaksi identtistä haposta ja kiviseinästä rakennettua figuuria, jotka muistuttavat ihmisen kasvoja. Radassa KSM reitti aloituspaikasta reikään kulkee kirjainten K-, S- ja M-muotoisten putkien sisällä. Nimi $M$-balls tulee radan keskellä sijaitsevista pyöreistä kiviseinämuodostelmista, jotka yhdessä muodostavat ison M-kirjaimen. Pull the anchor up! (kuva 2) taas liittyy radan keskellä olevaan suureen ankkuriin.

Kärkisijan nimien Acid Twins ja KSM kanssa jakaa Hookup \& Siam. Nimi on anagrammi kahden pitkäaikaisen aktiivipelaajan (Humis ja Koopa) nimistä. Anagrammi saattaisi muutoin olla vaikea huomata, mutta ratamestari on aikanaan paljastanut nimen taustan yhteisön IRC-kanavalla. Useat koehenkilöt mainitsivatkin vastauksissaan nimen yhteydestä pelaajayhteisön jäseniin. Sen voi otaksua edesauttaneen nimen muistamista, sillä myös kaksi muuta kokeissa esiintynyttä nimikkorataa (Star paw kokeessa 1 ja Moetikoitsijae kokeessa 2) on muistettu varsin hyvin.

8 Zolon minimitulosta (3 lyöntiä) pidetään yleisesti yhtenä Minigolfin helpoimmista ja tavoitelluimmista toistaiseksi saavuttamattomista ennätystuloksista. Eräs aktiivipelaaja on jopa rekisteröinyt Aapeliin käyttäjänimen saan zolon 3 . 
Lisäksi vaikuttaa siltä, että pelillisesti tärkeiden ja kiinnostavien ratojen nimet muistetaan hyvin. Taulukon 2 kärkipäässä on useita ratoja, joiden ennätystulos on pitkään ollut uniikki ${ }^{9}$, mm. Dance Sucker, Hooked at the horn, Boring Mill ja Just a Gigolo. Varsin hyvin on muistettu myös Estimation Quarter, joka kuuluu monien aktiivipelaajien suosikkeihin (kuten esimerkin 9 vastaus osoittaa) yksinkertaisen mutta silti runsaasti taitoa vaativan rakenteensa vuoksi. Joissakin tapauksissa nimi puolestaan on muistettu siksi, että rata on poikkeuksellisen tylsä tai huonosti suunniteltu ja herättää siksi negatiivisia tuntemuksia. Tästä kertovat ratoja varsin voimakkainkin sanankääntein evaluoivat vastaukset nimiin Siwali (esimerkit 10-11) ja First water then acid (esimerkit 12-13). Molemmat nimet sijoittuvat kokeen 2 kärkipäähän.

(9) paras rata, 5 lyönnin, 5 huonetta / nurmea, jäätä, hiekkaa, mäkeä

(10) about maailman tylsin rata, jossa pelkkää vettä ja ruohoa.

(11) siwali on sellanen ytylsä vettä rata / 7 lyönnil

(12) hoegin sotkurata missä bouncee reunalla -

(13) vittumainen neljän lyönnin rata. vasen ja oikea laita on sellasta puolikasta salmiakkikuviota. hyi vittu.

Ratasarjojen kohdalla voi tehdä saman havainnon kuin kokeessa 1: vastaajat pystyivät usein muistamaan, millaisia ratoja sarjaan kuuluu, mutta vain harvoin sen, mikä sarjanumero liittyy mihinkin rataan. Vielä kaksiosaiseen sarjaan kuuluvan Stone Passage Race II:n kohdalla useimmat pystyivät muistamaan tai päättelemään, kumpi radoista on kyseessä, mutta kolmiosaiseen ratasarjaan kuuluvien nimien (Beware water III, Minimalism I, Swinging III, Tradcave II) kohdalla muistaminen oli useimmille mahdotonta.

Kokeessa esiintyi runsaasti tilanteita, joissa nimi toi vastaajan mieleen väärän radan. Näin tapahtui paitsi ratasarjojen kohdalla, myös silloin, kun nimi on samankaltainen jonkin toisen radannimen kanssa. Esimerkiksi nimen Round an' round muisti oikein 5 vastaajaa, kun taas 9 vastaajaa alkoi kuvailla joko rataa Round and Round tai Awound an' awound. Nimen Pyramid kohdalla puolestaan 4 vastaajaa kuvaili oikeaa rataa, 9 vastaajaa taas jotakin neliosaisen Pyramid adventure -sarjan radoista. Sekaannuksia tapahtui runsaasti myös sellaisissa nimissä, jotka liittyvät radan pelaamiseen, esim. Estimation Quarter, Try once, Bouncy rooms ja Swinging III.

Kokeen 1 tavoin kokeessa 2 oli yksi rata, jonka nimeä kukaan vastaajista ei muistanut: Water corners. Tätä voi pitää jonkinlaisena yllätyksenä, sillä nimellä on selvä yhteys radan ominaisuuksiin, kulkureitin kulmissa sijaitseviin pieniin vesilammikoihin. Lammikot ovat kuitenkin kiviseinien rajaaman pelialueen ulkopuolella, joten pallo ei voi päätyä niihin - niinpä radan voi pelata läpi kiinnittämättä lammikoihin lainkaan huomiota. Nimen muistamista lienee vaikeuttanut myös se, että sanat water ja corner esiintyvät Minigolfin

9 Uniikilla tarkoitetaan Minigolfissa ennätystulosta, johon on pystynyt pelin historiassa vain yksi pelaaja. Ne ovat harvinaisia ja siksi erittäin arvostettuja saavutuksia. Ks. myös Hämäläinen 2016c, 6.29. 
radannimistössä melko taajaan ja ne ovat näin saattaneet johdattaa koehenkilöiden ajatukset useisiin eri ratoihin.

\section{Mitkä tekijät vaikuttavat muistettavuuteen?}

Edellä esitettyjen kvalitatiivisten havaintojen pohjalta voidaan tehdä alustavia johtopäätöksiä siitä, millä tekijöillä on vaikutusta nimen muistettavuuteen. Nämä johtopäätökset on kuitenkin syytä tarkistaa laskennallisesti. Tässä luvussa tarkastelen, millä tavoin erilaisia ominaisuuksia edustavat nimet on muistettu kokeissa. Käsittelen omissa alaluvuissaan viittä muuttujaa: nimenantoperustetta, nimen kuulumista ratasarjaan, nimen kieltä, nimen pituutta sekä radan pelillistä kiinnostavuutta. Lopuksi esitän lyhyen huomion ratojen koejärjestyksen vaikutuksesta tuloksiin.

Analysoin tuloksia Pearsonin $\chi^{2}$-testin avulla, joka on yksi yleisimmistä nominaaliasteikollisiin muuttujiin sovelletuista tilastollisista testeistä. Konventioista poiketen ilmoitan testien tulokset (ns.p-arvot) tarkkoina arvoina ${ }^{10}$ sen sijaan että tyytyisin ilmoittamaan, alittuvatko yleisimmin käytetyt tilastollisen merkitsevyyden rajat ( $p<0,05$; $p<0,01$; $p<$ 0,005; p < 0,001). Koska käytetty aineisto on kaikissa $\chi^{2}$-testeissä samansuuruinen, eri muuttujien p-arvoja keskenään vertailemalla voidaan arvioida, mitkä muuttujista vaikuttavat nimen muistamiseen vahvimmin ja mitkä vähemmän. Tarkastelen myös, missä taulukoiden soluissa havaittu tulos poikkeaa odotetusta eniten. Tästä kertoo ns. standardoitu jäännös eli havaitun arvon ja odotusarvon neliöity erotus ${ }^{11}$. Yksittäisen taulukon solun standardoitua jäännöstä pidetään yleensä tilastollisesti merkitsevänä, kun se on yli 1,96 (esim. White 1970), mutta mitä suurempi luku on, sitä vahvempi on muuttujan vaikutus koetuloksiin.

Artikkelin pituusrajoituksen vuoksi pystyn esittämään vain kiinnostavimpia poimintoja $\chi 2$-testien tuloksista. Täydelliset taulukot havaituista arvoista, odotusarvoista ja standardoiduista jäännöksistä löytyvät liitteestä 1 .

\subsection{Nimenantoperuste}

Luvussa 4 osoitin, että tuloslistojen yläpäässä esiintyy runsaasti radan ominaisuuksiin, etenkin muotoihin, liittyviä nimiä, mm. Candle in the wind ja Pull the anchor up!. Tämä antaa olettaa, että nimenantoperuste on yksi nimen muistettavuuteen olennaisimmin vaikuttavista tekijöistä.

Kuten luvussa 2 totesin, jotkin Minigolfin radannimet kuuluvat samanaikaisesti useampaan kuin yhteen nimenantoperusteiden luokkaan. Jotta $\chi^{2}$-testi toimisi

10 Paikoitellen olen ilmaissut tulokset kymmenpotenssimuodossa: esimerkiksi $1,4 \cdot 10^{-12}=$ 0,0000000000014 .

11 Standardoidun jäännöksen (engl. adjusted residual) ohella suomessa käytetään termiä $\chi 2$-kontribuutio, ks. Vehkalahti 2014, 184. 
ongelmattomasti, on jokainen nimi sijoitettava vain yhteen noista luokista. Tämän vuoksi olen tätä testiä varten valinnut kunkin nimen ensisijaisen nimenantoperusteen. Esimerkiksi Candle in the windin ensisijaisena nimenantoperusteena olen pitänyt radassa esiintyvää muotoa (kynttiläfiguuri) enkä intertekstuaalista viittausta, sillä yhteys muotoon lienee ilmeisempi eikä edellytä radanulkoisen maailman (musiikkikappaleen) tuntemista.

Tulkintani mukaan kokeen 1 nimistä 11 liittyy ensisijaisesti rataelementtiin, 12 radassa esiintyvään muotoon, 16 radan pelaamiseen ja 11 ei liity radan ominaisuuksiin. Olen koonnut näiden neljän ryhmän prosentuaaliset vastausjakaumat taulukkoon 3. Kuten taulukosta havaitaan, ryhmien välillä on huomattavia eroja. Radan muotoon liittyvien nimien kohdalla 2 tai 1 pisteen vastauksia on yhteensä $45 \%$, radan ominaisuuksiin liittymättömien nimien kohdalla vain $17 \%$. $\chi^{2}$-testin tulos $\left(\chi^{2}[6]=67,39 ; p=1,4 \cdot 10^{-12}\right)$ osoittaa, että erot luokkien välillä ovat tilastollisesti erittäin merkitseviä. Standardoituja jäännöksiä tarkastelemalla voidaan todeta, että etenkin radan ominaisuuksiin liittymättömien nimien osittain oikeiden vastausten määrä on huomattavan pieni (st. jäännös 25,40) ja muotoon liittyvien nimien täysin oikeiden vastausten määrä huomattavan suuri (st. jäännös 10,34).

Kokeessa 2 esiintyneistä nimistä 16 liittyy ensisijaisesti rataelementtiin, 6 radassa esiintyvään muotoon, 14 radan pelaamiseen ja 14 ei liity radan ominaisuuksiin. Taulukko 3 kertoo, että parhaiten on muistettu radan muotoon liittyvät ja radan ominaisuuksiin liittymättömät nimet, heikoiten taas radan pelaamiseen liittyvät nimet. $\chi^{2}$-testi osoittaa, että erot luokkien välillä ovat tilastollisesti merkitseviä $\left(\chi^{2}[6]=31,10 ; p=2,4 \cdot 10^{-5}\right)$, joskin vähemmän selvästi kuin kokeessa 1 . Erityisesti radan pelaamiseen liittyvien nimien täysin oikeiden vastausten määrä on merkillepantavan pieni (st. jäännös 8,93).

Taulukko 3. Koevastausten jakauma nimenantoperusteiden perusteella (\%).

\begin{tabular}{|r|c|c|c|c|c|c|}
\hline & \multicolumn{3}{|c|}{ Koe 1 } & \multicolumn{3}{c|}{ Koe 2 } \\
\hline Peruste & $\mathbf{2 p}$ & $\mathbf{1 p}$ & op & $\mathbf{2 p}$ & $\mathbf{1 p}$ & op \\
\hline Rataelementti & 18,5 & 14,3 & 67,1 & 25,0 & 8,1 & 66,9 \\
\hline Radan muoto & 30,8 & 14,1 & 55,1 & 31,7 & 15,0 & 53,3 \\
\hline Pelaaminen & 21,4 & 11,1 & 67,5 & 16,1 & 11,4 & 72,5 \\
\hline Ei liity omin. & 16,4 & 0,7 & 82,9 & 31,1 & 5,4 & 63,6 \\
\hline
\end{tabular}

Radassa esiintyvään muotoon liittyvät nimet on siis muistettu parhaiten kummassakin kokeessa. Tämä on linjassa aiempien tutkimusten kanssa. Esimerkiksi Serge Brédart ja Tim Valentine (1998) sekä Kethera Fogler ja Lori James (2007) ovat havainneet nimen olevan helpompi muistaa, mikäli kohteen nimen ja ominaisuuksien välillä on selkeä ja ymmärrettävä yhteys. Fogler, James ja Crandall (2010) puolestaan ovat todenneet, että kohteensa fyysisiä ominaisuuksia kuvaavat nimet muistetaan paremmin kuin mentaalisia ominaisuuksia kuvaavat. Radan muoto voitaneen rinnastaa fyysisiin ominaisuuksiin, sillä 
yhteyden nimeen voi usein nähdä vain rataa katsomalla. Radan pelattavuus puolestaan muistuttaa enemmän mentaalista ominaisuutta, sillä nimenantoperuste ei ole aina päällepäin (varsinkaan kokemattoman pelaajan) nähtävissä, vaan sen ymmärtäminen edellyttää radan pelaamista. Kokeiden tulokset ovat myös osin vastakkaiset. Radan pelaamiseen liittyvät nimet on muistettu kokeessa 1 melko hyvin mutta kokeessa 2 selvästi heikoiten, radan ominaisuuksiin liittymättömät nimet puolestaan kokeessa 1 heikoiten mutta kokeessa 2 varsin hyvin. Tätä ristiriitaa voidaan osittain selittää kokeessa 2 esiintyneillä virheellisillä muistikuvilla. Radan pelaamiseen liittyvät nimet sopisivat yleensä kuvailemaan useatakin Minigolfin radoista, joten koehenkilöt ymmärrettävästi aika ajoin erehtyivät muistelemaan väärää rataa. Sen sijaan radan ominaisuuksiin liittymättömät nimet herättivät vääriä muistikuvia harvoin, ne joko muistettiin oikein tai ne eivät herättäneet mitään mielikuvia. Tätä havaintoa vahvistaa se, että radan ominaisuuksiin liittymättömien nimien osittain oikeiden vastausten määrä jäi molemmissa kokeissa hyvin pieneksi.

\subsection{Kuuluminen ratasarjaan}

Yhdeksi selitykseksi nimien muistamisen vaikeudelle on tarjottu niiden alhaista käyttöfrekvenssiä (Burke ym. 1991; Brédart 2016, 485-487). Koska nimet viittaavat vain yhteen kohteeseen, ei niitä yleensä käytetä yhtä usein kuin lukuisiin tietyntyyppisiin kohteisiin viittaavia appellatiiveja. Minigolfissa ratasarjojen nimet kuitenkin viittaavat useaan kohteeseen, joten niitä on tarpeen käyttää keskimäärin useammin kuin muita nimiä. Toisaalta nimien samankaltaisuus voi tehdä niiden erottamisen toisistaan vaikeaksi. Ratasarjaan kuuluminen voi siis potentiaalisesti sekä helpottaa että vaikeuttaa nimen muistamista.

Kokeessa 1 esiintyneistä radoista johonkin ratasarjaan kuuluu 12 ja ei kuulu 38 rataa. Kuten taulukosta 4 havaitaan, nämä kaksi ryhmää ovat keränneet täysin oikeita vastauksia jokseenkin yhtä paljon, mutta osittain oikeita vastauksia on ratasarjaan kuuluvien nimien kohdalla valtavasti enemmän. Tilastollinen merkitsevyys on tämän tutkimuksen toiseksi suurin $\left(\chi_{2}[2]=78,97 ; p=7,1 \cdot 10^{-18}\right)$, ja valtaosan siitä muodostavat erot osittain oikeiden vastausten määrässä (st. jäännökset 52,87 ja 16,70).

Kokeessa 2 esiintyneistä radoista johonkin ratasarjaan kuuluu 10 ja ei kuulu 40 rataa. Päinvastoin kuin kokeessa 1, ratasarjaan kuuluvat nimet on muistettu muita heikommin. Ne ovat keränneet enemmän osittain oikeita mutta toisaalta selvästi vähemmän täysin oikeita vastauksia kuin ratasarjaan kuulumattomat nimet. Nämä erot ovat tilastollisesti merkitseviä $\left(\chi^{2}[2]=21,39 ; \mathrm{p}=2,3 \cdot 10^{-5}\right)$, joskaan eivät yhtä selvästi kuin kokeessa 1 .

Taulukko 4. Koevastausten jakauma ratasarjaan kuulumisen perusteella (\%).

\begin{tabular}{|r|c|c|c|c|c|c|}
\hline & \multicolumn{3}{|c|}{ Koe 1 } & \multicolumn{3}{c|}{ Koe 2 } \\
\hline Ratasarja & $\mathbf{2 p}$ & $\mathbf{1 p}$ & op & $\mathbf{2 p}$ & $\mathbf{1 p}$ & op \\
\hline Kuuluu & 21,2 & 23,4 & 55,4 & 14,5 & 15,0 & 70,5 \\
\hline Ei kuulu & 22,2 & 6,1 & 71,8 & 27,6 & 7,6 & 64,8 \\
\hline
\end{tabular}


Kokeiden päinvastaisia tuloksia voidaan selittää ennen kaikkea kokeiden toteutus- ja pisteytystavalla. Suhteellisen vaivattomassa kokeessa 1 epävarmatkin vastaajat arvailivat hanakasti ja saivat usein vähintään yhden pisteen, kun taas työläämmässä kokeessa 2 vastaajat eivät ryhtyneet yhtä innokkaasti epävarmoihin arvauksiin ja jäivät pisteittä.

Yleishavainto molempien kokeiden osalta on kuitenkin sama: ratasarjaan kuulumisesta on muistettavuuden kannalta sekä etua että haittaa. Sarjojen nimet muistetaan yksittäisten ratojen nimiä paremmin, mutta oikeiden sarjanumeroiden muistaminen on harvinaista. Tälle havainnolle voidaan löytää analogioita myös reaalimaailmasta. On esimerkiksi todettu, että suomalaisessa kadunnimistössä yleiset ryhmä- eli aihepiirinimet, yhteisen teeman mukaan tietylle alueelle luodut kadunnimet, helpottavat paikan etsijää löytämään oikean alueen mutta vaikeuttavat täsmälleen oikean kadun löytämistä ( $\mathrm{mm}$. Närhi 1999, 26-27; Ainiala 2016b, 109-110, 116).

On myös syytä huomauttaa, että ratasarjat eivät ole muistettavuuden kannalta täysin yhtenäinen kategoria, vaan ryhmän sisällä on vaihtelua. Tuloksissa on havaittavissa viitteitä siitä, että kaksiosaiseen sarjaan kuuluvat nimet (mm. Siwali; Stone Passage Race II) muistetaan useampiosaiseen sarjaan kuuluvia paremmin ja lisäyksen tai vaihdon sisältävät nimet (mm. Beach Mission: Acid Factory; Dream of Four Strokes) numerosarjan sisältäviä nimiä paremmin. Näihin alaryhmiin kuuluvien nimien määrät muistikokeissa ovat liian pienet, jotta havaintoja voisi vahvistaa laskennallisesti. Havainnot ovat silti kiinnostavia, sillä niitä voidaan mahdollisesti soveltaa myös muihin nimikategorioihin. Lisäyksen sisältävät nimet vertautuvat esimerkiksi reaalimaailman paikannimistön liitynnäisiin taikka elokuvien jatko-osien nimiin (esim. Terminator 2: Judgment Day), vaihdon sisältävät nimet puolestaan paikannimistön vastakohta- ja variointinimiin. Vaihtelu erityyppisten ratasarjojen muistettavuudessa olisikin hedelmällinen jatkotutkimuksen aihe.

\subsection{Nimen kieli}

Nimen kieli vaikuttaa sen ymmärrettävyyteen ja siten mahdollisesti myös muistamiseen. Minigolfin radannimet ovat valtaosin englantia, jota koehenkilöiden, verkossa aktiivisesti toimivien nuorten aikuisten, voidaan olettaa osaavan keskimäärin varsin hyvin. Muunkielisten nimien (pois lukien suomenkielisten nimien pieni joukko) sisällön ymmärtäminen sen sijaan saattaa olla haastavampaa, tekosanojen kohdalla ajoittain jopa mahdotonta. Luvussa 4 teinkin laadullisen havainnon, että tekosananimet on muistettu keskimäärin varsin heikosti.

Kokeen 1 nimistä englanninkielisiä on 45 ja tekosanoja 4 (Calicula, Fivagon, WeeWoo, Zolo). ${ }^{12}$ Kuten taulukosta 5 havaitaan, tekosananimet ovat keränneet selvästi vähemmän sekä täysin että osittain oikeita vastauksia. Tilastollinen merkitsevyys ( $\chi^{2}[2]=17,45 ; \mathrm{p}=$ 0,00016) ei kuitenkaan ole yhtä selvä kuin luvuissa 5.1 ja 5.2, sillä tekosananimien määrä otoksessa on hyvin pieni. Joka tapauksessa tulos vahvistaa käsitystä siitä, että taustaltaan

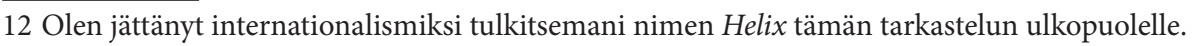


ymmärrettävä nimi on helpompi muistaa (luku 5.1; Brédart-Valentine 1998; FoglerJames 2007).

Taulukko 5. Koevastausten jakauma nimen kielen perusteella (\%).

\begin{tabular}{|r|c|c|c|}
\hline & \multicolumn{3}{|c|}{ Koe 1 } \\
\hline Nimen kieli & $\mathbf{2 p}$ & $\mathbf{1 p}$ & op \\
\hline Englanti & 22,6 & 11,3 & 66,2 \\
\hline Tekosana & 14,4 & 1,0 & 84,6 \\
\hline
\end{tabular}

Kokeessa 2 tekosananimiä oli vain kaksi kappaletta (Eone, Siwali), joten en nähnyt mielekkääksi lähteä tekemään $\chi^{2}$-testejä tai muita päätelmiä niiden perusteella.

\subsection{Nimen pituus}

Aiemmassa tutkimuskirjallisuudessa on yleensä oletettu, että lyhyet nimet muistetaan pitkiä paremmin (esim. Sjöblom 2016, 460). Tutkimustietoa aiheesta on vähän, mutta ainakin Hanleyn ja Eleanor Chapmanin (2008) tutkimus kaksi- ja kolmiosaisten henkilönnimien muistamisesta tukee oletusta. Syitä lyhyiden nimien helpompaan muistamiseen ei yleensä eksplikoida, mutta luultavasti päättely perustuu yksinkertaisesti siihen, että lyhyessä nimessä on vähemmän muistettavaa ainesta kuin pitkässä. Nimen pituus voidaan toki määritellä monella tapaa, ainakin kirjain-, tavu- tai sanamäärän perusteella. Tässä artikkelissa tarkastelen nimiä niiden sanamäärän perusteella. Olen kuitenkin tehnyt $\chi^{2-}$ testit myös kirjainmäärän perusteella (ks. liite 1), ja tulokset ovat samansuuntaisia.

Kokeessa 1 esiintyneistä nimistä 15 sisältää yhden sanan, 20 kaksi sanaa ja 15 kolme sanaa tai enemmän ${ }^{13}$. Kuten taulukosta 6 havaitaan, pitkät nimet on muistettu selvästi lyhyitä paremmin. Vähintään kolmen sanan nimet ovat keränneet eniten sekä täysin että osittain oikeita vastauksia, ja kahden sanan nimet on muistettu yhden sanan nimiä paremmin. $\chi^{2}$-testi kertoo, että tilastollinen merkitsevyys on koko tämän tutkimuksen suurin $\left(\chi_{2}^{2}[4]=94,94 ; p=1,2 \cdot 10^{-19}\right)$. Suurimmat poikkeamat odotusarvoista ovat osittain oikeiden vastausten luokassa, joita on yhden sanan nimissä erittäin vähän (st. jäännös 28,80 ) ja vähintään kolmen sanan nimissä erittäin paljon (st. jäännös 27,46). Tämä lienee täysin odotuksenmukaista. Yhden sanan nimissä harvoin tehdään virheitä - ne joko muistetaan kokonaan tai ei ollenkaan - kun taas pidemmät nimet ovat alttiimpia pienille virheille. Yllättävää sen sijaan on, että pitkät nimet ovat keränneet lyhyitä enemmän myös täysin oikeita vastauksia.

Kokeessa 2 esiintyneistä nimistä 19 sisältää yhden sanan, 18 kaksi sanaa ja 13 kolme sanaa tai enemmän. Kuten taulukosta 6 voidaan havaita, vähintään kolme sanaa sisältävät

13 Olen laskenut erillisiksi sanoiksi myös artikkelit, prepositiot, \&-merkin sekä ratasarjojen sarjanumerot. 
nimet ovat keränneet eniten oikeita vastauksia, mutta erot ryhmien välillä ovat varsin pienet. $\chi^{2}$-testin tulos $\left(\chi_{2}[4]=6,11 ; p=0,191\right)$ kertookin, että erot eivät ole tilastollisesti merkitseviä.

Taulukko 6. Koevastausten jakauma nimen pituuden perusteella (\%).

\begin{tabular}{|r|c|c|c|c|c|c|}
\hline & \multicolumn{3}{|c|}{ Koe 1 } & \multicolumn{3}{c|}{ Koe 2 } \\
\hline Nimen pituus & $\mathbf{2 p}$ & $\mathbf{1 p}$ & op & $\mathbf{2 p}$ & $\mathbf{1 p}$ & op \\
\hline 1 sana & 15,4 & 1,5 & 83,1 & 24,7 & 9,5 & 65,8 \\
\hline 2 sanaa & 22,5 & 10,4 & 67,1 & 21,9 & 9,4 & 69,2 \\
\hline Enemmän & 27,7 & 18,7 & 53,6 & 30,4 & 8,1 & 61,5 \\
\hline
\end{tabular}

Koetulokset ovat siis jälleen vastakkaiset: kokeessa 1 pitkät nimet on kenties odotuksenvastaisesti muistettu lyhyitä paremmin, kun taas kokeessa 2 nimen pituudella ei ole ollut tilastollisesti merkitsevää vaikutusta sen muistamiseen. Ristiriitaa voitaneen osittain selittää luvuissa 5.1 ja 5.2 käsiteltyjen muuttujien vaikutuksella. Lyhyet ja pitkät nimet ovat myös nimeämisperusteiltaan jossain määrin erilaisia: yhden sanan nimistä peräti $38 \%$ ei liity radan ominaisuuksiin, kun taas kaksisanaisista nimistä tällaisia on $25 \%$ ja useampisanaisista nimistä $24 \%$. Kuten luvussa 5.1 havaittiin, radan ominaisuuksiin liittymättömät nimet muistettiin kokeessa 1 selvästi huonoiten, kokeessa 2 puolestaan varsin hyvin. Ratasarjoihin kuuluvien ratojen nimet puolestaan ovat keskimäärin muita pidempiä ${ }^{14}$. Kuten luvussa 5.2 havaittiin, ratasarjoihin kuuluvat nimet muistettiin kokeessa 1 selvästi paremmin mutta kokeessa 2 jonkin verran huonommin kuin sarjoihin kuulumattomat nimet.

Edellä esitetyt yhteydet radannimien pituuden sekä nimenantoperusteen tai ratasarjaan kuulumisen välillä luonnollisesti pätevät vain Minigolfissa, joten koetuloksista ei voi tehdä suoria rinnastuksia muihin nimikategorioihin. Oletukseen siitä, että lyhyet nimet muistettaisiin pitkiä paremmin, on kuitenkin ilman tarkempaa tutkimustietoa syytä suhtautua varauksella.

\subsection{Radan pelillinen kiinnostavuus}

Nimen muistettavuuteen vaikuttavat luonnollisesti muutkin tekijät kuin itse nimi ja sen ominaisuudet. Erityisen tärkeänä tai kiinnostavana pidetyn kohteen nimen muistaminen on todennäköistä, sillä nimeä on luultavasti tarpeen käyttää usein ja motivaatio sen oppimiseen on korkea (Burke ym. 1991; Hanley-Chapman 2008).

Minigolfissa radat voivat olla hyvinkin erilaisia keskenään. Toiset radat ovat lyhyitä, helppoja ja yksinkertaisia, toiset taas pitkiä, vaikeita ja monimutkaisia. Myös ratojen pelillisessä kiinnostavuudessa on valtavia eroja. Aktiivipelaajien näkökulmasta tärkeimpiä ja

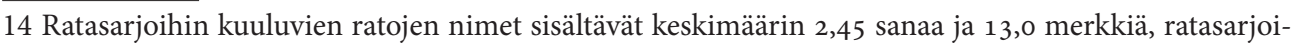
hin kuulumattomien puolestaan 1,97 sanaa ja 11,3 merkkiä. 
kiinnostavimpia ovat yleensä vaikeat radat, kun taas helpot radat ovat tylsiä ja yhdentekeviä. Toisaalta kiinnostavuus muodostuu usean tekijän summana. Vaikka esimerkiksi radan pituus ja tiettyjen rataelementtien käyttö korreloivat jossain määrin kiinnostavuuden kanssa, ei kiinnostavuutta voi pelkistää yksin näihin muuttujiin. Jotta voin tarkastella kiinnostavuuden vaikutusta nimen muistamiseen, on minun ensin määriteltävä tämä muuttuja kunkin radan osalta.

Olen jakanut muistikokeissa esiintyneet radat kolmeen ryhmään: pelilliseltä kiinnostavuudeltaan tavallisiin, tavallista tylsempiin sekä tavallista kiinnostavampiin. Käytän näistä ryhmistä jatkossa nimityksiä "tavalliset", "tylsät" ja "kiinnostavat". Kiinnostavuus on toki jossain määrin subjektiivista, eri pelaajat pitävät eri ratoja kiinnostavina. Olen pyrkinyt ottamaan tämän huomioon. En siis ole tehnyt luokitusta omien mielipiteideni mukaisesti vaan kokemukseni perusteella arvioiden, mitä mieltä yhteisön jäsenet keskimäärin ovat kustakin radasta. Olen näyttänyt tekemääni jakoa joillekin yhteisön jäsenille, ja he pitivät sitä onnistuneena.

Radan kiinnostavuus riippuu suuresti myös pelimuodosta. Yksinpelissä kiinnostavimpina pidetään sellaisia ratoja, joissa on mahdollista saavuttaa uusi rataennätys tai sivuta harvinaista ennätystulosta. Moninpelissä ${ }^{15}$ sen sijaan kiinnostavimpia ovat radat, joissa pelaajien välille voi syntyä suuriakin eroja. Sama rata voi siis olla yksinpelissä kiinnostava mutta moninpelissä tylsä tai päinvastoin. Tästä syytä olen tehnyt erilliset ryhmittelyt yksin- ja moninpelin osalta.

Taulukko 7. Koevastausten jakauma radan yksinpelikiinnostavuuden perusteella (\%).

\begin{tabular}{|r|c|c|c|c|c|c|}
\hline & \multicolumn{3}{|c|}{ Koe 1 } & \multicolumn{3}{c|}{ Koe 2 } \\
\hline Kiinnostavuus & $\mathbf{2 p}$ & $\mathbf{1 p}$ & op & 2p & 1p & op \\
\hline Tylsä & 13,1 & 11,5 & 75,3 & 17,5 & 10,0 & 72,5 \\
\hline Tavallinen & 25,6 & 9,2 & 65,2 & 23,1 & 8,8 & 68,1 \\
\hline Kiinnostava & 27,4 & 10,0 & 62,6 & 34,1 & 8,2 & 61,3 \\
\hline
\end{tabular}

Yksinpelistä olen luokitellut kokeen 1 radoista 17 tylsiksi, 18 tavallisiksi ja 15 kiinnostaviksi. Kuten taulukosta 7 havaitaan, kiinnostavien ja tavallisten ratojen nimet on muistettu jokseenkin yhtä hyvin mutta tylsien ratojen nimet selvästi heikoimmin. $\chi^{2}$-testin tulos $\left(\chi^{2}[4]=30,99 ; p=3,1 \cdot 10-6\right)$ vahvistaa, että erot ovat tilastollisesti merkitseviä. Erityisesti tylsien ratojen oikeiden vastausten määrä on huomattavan pieni (st. jäännös 15,61). Kokeen 2 radoista olen luokitellut yksinpelin kannalta tylsiksi 16, tavallisiksi 16 ja kiinnostaviksi $17 \cdot{ }^{16}$ Kiinnostavat radat on muistettu parhaiten ja tylsät heikoiten. $\chi^{2}$-testin

15 Sanaa moninpeli käytetään useilla suomenkielisillä pelisivustoilla (ml. Aapeli) useamman kuin yhden pelaajan peleistä silloin, kun tarkkaa pelaajamäärää ei ole spesifioitu (vrt. kaksinpeli, nelinpeli).

16 Rata Blue Moment ei esiinny yksinpelissä lainkaan, joten olen jättänyt sen tämän luokittelun ulkopuolelle. 
tulos $\left(\chi^{2}[4]=25,74 ; p=4,3 \cdot 10^{-5}\right)$ osoittaa, että erot ovat tilastollisesti merkitseviä. Eniten odotusarvosta poikkeaa kiinnostavien ratojen oikeiden vastausten suuri määrä (st. jäännös 11,01).

Moninpelin osalta olen luokitellut kokeen 1 radoista 16 tylsiksi, 19 tavallisiksi ja 15 kiinnostaviksi. Kuten taulukosta 8 havaitaan, kiinnostavien ratojen nimet on muistettu parhaiten mutta tylsien ratojen nimet yllättäen hieman tavallisia paremmin. Erot luokkien välillä kuitenkin ovat suhteellisen pienet. $\chi^{2}$-testin tulos $\left(\chi^{2}[4]=22,50 ; p=0,00016\right)$ ylittää tilastollisen merkitsevyyden rajat, joskin niukemmin kuin useimmilla muilla muuttujilla. Suurimman osan tästä merkitsevyydestä muodostavat osittain oikeat vastaukset, joita on tylsien ratojen kohdalla paljon (st. jäännös 6,35) ja tavallisten ratojen kohdalla vähän (st. jäännös 10,35). En osaa selittää tätä kuin sattumalla: tylsien ratojen luokkaan on osunut seitsemän ja tavallisten vain kaksi ratasarjaan kuuluvaa nimeä, mikä aiheuttaa poikkeamat osittain oikeiden vastausten määrässä.

Kokeen 2 radoista olen luokitellut moninpelissä tylsiksi 19, tavallisiksi 17 ja kiinnostaviksi 14. Kiinnostavuus korreloi jälleen vahvasti koemenestyksen kanssa: kiinnostavat radat on muistettu parhaiten ja tylsät heikoiten. $\chi \chi^{2}$-testin perusteella tilastollinen merkitsevyys on hyvin selvä $\left(\chi^{2}[4]=43,15 ; p=9,6 \cdot 10^{-9}\right)$. Etenkin tylsien ratojen täysin oikeiden vastausten määrä on huomattavan pieni (st. jäännös 16,04).

Taulukko 8. Koevastausten jakauma radan moninpelikiinnostavuuden perusteella (\%).

\begin{tabular}{|r|c|c|c|c|c|c|}
\hline & \multicolumn{3}{|c|}{ Koe 1 } & \multicolumn{3}{c|}{ Koe 2 } \\
\hline Kiinnostavuus & $\mathbf{2 p}$ & $\mathbf{1 p}$ & op & $\mathbf{2 p}$ & $\mathbf{1 p}$ & op \\
\hline Tylsä & 19,5 & 14,2 & 66,3 & 14,4 & 11,4 & 74,2 \\
\hline Tavallinen & 21,9 & 5,7 & 72,5 & 28,6 & 5,6 & 65,8 \\
\hline Kiinnostava & 24,6 & 11,8 & 63,6 & 33,9 & 10,7 & 55,4 \\
\hline
\end{tabular}

Tulokset kertovat, että kiinnostavien ratojen nimet muistetaan paremmin kuin tylsien ja yhdentekevien. Tämä on täysin odotuksenmukaista. Pelaajat kiinnittävät kiinnostaviin ratoihin enemmän huomiota, ja niistä myös keskustellaan useammin, joten niiden nimien osaaminen on tarpeellisempaa. On kuitenkin syytä huomata, että tilastolliset merkitsevyydet eivät ole yhtä suuria kuin esimerkiksi nimenantoperusteen tai ratasarjaan kuulumisen kohdalla. Voidaan siis todeta, että nimen muodolla ja sisällöllä on suuri vaikutus sen muistamiseen.

\subsection{Ratojen järjestys muistikokeissa}

Muistikokeiden radat esitettiin kaikille koehenkilöille samassa järjestyksessä. Kummankin kokeen ensimmäinen rata (Narrow squeak ja Acid Twins) löytyy aivan tuloslistojen huipulta, minkä vuoksi on syytä epäillä, että ratojen esiintymisjärjestys kokeissa on voinut 
vaikuttaa tuloksiin. Varsinkin koe 2 osoittautui melko raskaaksi, joten vastaajien vireystila ja suoritustaso ovat saattaneet laskea sen aikana.

Tulkinnalle löytyy myös lievää laskennallista tukea. Olen jakanut kummankin kokeen radat kolmeen samansuuruiseen ryhmään niiden koejärjestyksen perusteella. Kuten taulukosta 9 nähdään, kummassakin kokeessa viimeiseen kolmannekseen kuuluneet radat on muistettu hieman muita huonommin. Tulkintaa kokeen 2 raskaudesta tukee se, että luokkien väliset erot ovat siinä tilastollisesti merkitsevämmät $\left(\chi^{2}[4]=12,09 ; \mathrm{p}=0,017\right)$ kuin kokeessa $1\left(\chi^{2}[4]=9,11 ; p=0,058\right)$.

Taulukko 9. Koevastausten jakauma ratojen koejärjestyksen perusteella (\%).

\begin{tabular}{|r|c|c|c|c|c|c|}
\hline & \multicolumn{3}{|c|}{ Koe 1 } & \multicolumn{3}{c|}{ Koe 2 } \\
\hline Koejärjestys & $\mathbf{2 p}$ & $\mathbf{1 p}$ & op & $\mathbf{2 p}$ & $\mathbf{1 p}$ & op \\
\hline Radat 1-17 & 23,1 & 9,7 & 67,2 & 27,6 & 9,7 & 62,6 \\
\hline Radat 18-34 & 22,4 & 13,1 & 64,5 & 27,4 & 10,6 & 62,1 \\
\hline Radat 35-50 & 20,2 & 7,7 & 72,1 & 19,7 & 6,9 & 73,4 \\
\hline
\end{tabular}

Ratojen järjestyksen vaikutus koetuloksiin on kuitenkin selvästi pienempi kuin aiemmin tässä luvussa käsiteltyjen muuttujien. Ei myöskään ole havaittavissa, että koejärjestys olisi vaikuttanut analyysin tuloksiin muiden muuttujien osalta. Ratojen esiintymisjärjestys oli arvottu, joten erilaisia ominaisuuksia edustavien nimien voidaan olettaa jakautuneen varsin tasaisesti kokeiden eri vaiheisiin.

\section{Lopuksi}

Aiemmat tutkimukset ovat osoittaneet, että nimien muistaminen on vaikeampaa kuin muiden kielen sanojen. Tutkimuksissa ei kuitenkaan ole juuri huomioitu sitä, että nimien muistamisessa on eroja paitsi ihmisyksilöiden, myös erilaisten nimien välillä. Tässä tutkimuksessa on selvitetty, mitkä tekijät vaikuttavat nimen muistettavuuteen. Aineistona on käytetty verkkopeliyhteisö Aapelissa sijaitsevaa virtuaalipeliä, Minigolfia. Pelin aktiiviset harrastajat ovat osallistuneet kahteen toteuttamaani muistikokeeseen, joista toisessa heidän tehtävänään on ollut muistaa pelin radannimiä niiden kuvien perusteella ja toisessa kuvailla ratoja niiden nimien perusteella. Koetulokset osoittavat suuria eroja nimien muistettavuudessa. Jotkin nimet muisti enemmistö koehenkilöistä, joitakin taas ei yksikään henkilö.

Jo tuloksia kvalitatiivisesti analysoimalla on mahdollista havaita useita syitä, miksi toiset nimet muistetaan ja toisia ei. Näiden havaintojen perusteella valitsin tarkempaan kvantitatiiviseen analyysiin viisi muuttujaa: nimenantoperuste, kuuluminen ratasarjaan, nimen kieli, nimen pituus sekä radan pelillinen kiinnostavuus. Nimenantoperusteiden 
ryhmistä parhaiten muistettiin radan muotoihin liittyvät nimet, heikoiten taas kokeessa 1 radan ominaisuuksiin liittymättömät nimet ja kokeessa 2 radan pelaamiseen liittyvät nimet. Ratasarjojen nimet muistettiin yksittäisten ratojen nimiä paremmin, mutta nimiin kuuluvat sarjanumerot muistettiin vain harvoin oikein. Englanninkieliset nimet muistettiin tekosananimiä paremmin. Pitkät nimet muistettiin kokeessa 1 lyhyitä paremmin, kokeessa 2 taas nimen pituus ei vaikuttanut sen muistamiseen. Radan pelillinen kiinnostavuus edesauttoi nimen muistamista. Kokonaisuudessaan voidaan todeta, että nimen muistettavuus on monen tekijän summa. Siihen vaikuttavat niin nimen kuin itse kohteen ominaisuudet.

Voidaan pitää kiinnostavana, että kahden muistikokeen tulokset ovat monelta osin erilaiset tai jopa päinvastaiset. Molemmat kokeet pyrkivät simuloimaan todellista keskustelutilannetta, joskin eri rooleissa: kokeessa 1 koehenkilö asetettiin puhujan, kokeessa 2 kuulijan asemaan. Toisaalta tulosten eroavuus ei välttämättä ole yllättävää, sillä kyseessä on kaksi jossain määrin erilaista kognitiivista prosessia. Kokeen 2 tehtävästä voitaisiinkin puhua nimen muistamisen sijaan esimerkiksi nimen tunnistamisena.

Muistikokeet olivat sekä onomastiikan että fennistiikan kontekstissa toteutustavaltaan varsin poikkeuksellisia, joten lienee syytä arvioida lyhyesti niiden onnistuneisuutta ja käyttökelpoisuutta jatkossa. Koe 1 oli nähdäkseni kokonaisuutena varsin onnistunut. Koe 2 tuotti runsaasti mielenkiintoista, myös jatkotutkimusten kannalta käyttökelpoista aineistoa. Toisaalta se oli koehenkilöille varsin työläs, mistä kertoo lievä suoritustason lasku kokeen loppua kohden. Vaihtoehto radan vapaamuotoiselle kuvaamiselle voisi olla pyytää koehenkilöitä vastaamaan muutamaan radan ominaisuuksiin liittyvään monivalintakysymykseen. Ratojen määrä (50 per koe) oli varsin suuri - pienempikin määrä olisi riittänyt tarpeeksi suuren aineiston keräämiseksi. Toisaalta potentiaalisten koehenkilöiden määrä oli varsin pieni, joten päätin varmuuden vuoksi kerätä mieluummin liikaa kuin liian vähän aineistoa. Kokeiden toteuttaminen verkon välityksellä ei aiheuttanut ongelmia. En havainnut merkkejä vilpistä koetilanteissa, ja muutoinkin käytännön järjestelyt sujuivat hyvin.

Empiiriset kokeet ovat nähdäkseni mainio tapa tutkia nimien muistamista. Niiden avulla on mahdollista kerätä suurehkojakin aineistoja kohtuullisella vaivalla. Toinen vaihtoehto olisi analysoida autenttisia keskusteluaineistoja, mutta nimien muistamiseen liittyvien katkelmien löytäminen niistä olisi työlästä. Niinpä aineisto luultavasti jäisi pienemmäksi ja tilastollinen merkitsevyys saattaisi jäädä saavuttamatta.

Nimien muistaminen on tärkeää ja hyödyllistä. Tämä tutkimus antaa olettaa, että onnistuneella nimenannolla voidaan vaikuttaa huomattavasti siihen, kuinka hyvin nimi muistetaan. Tutkimuskohteena toki oli vain yhden verkkopelin nimistö, mutta sillä on useita yhtymäkohtia muihin erisnimikategorioihin, kuten kadunnimiin, maaseudun perinnäiseen paikannimistöön sekä erilaisten taideteosten nimiin (ks. myös Hämäläinen 2018). Olisi kiinnostavaa nähdä vastaavanlaisia tutkimuksia myös muista nimikategorioista. Todennäköisesti on eroja mutta myös runsaasti yhtäläisyyksiä siinä, mitkä tekijät nimen muistettavuuteen vaikuttavat. 


\section{Lähteet}

AAPELI 2002: Minigolf. Suomi, Apaja Creative Solutions Oy. Saatavilla www.aapeli.com/pelaa/minigolf [viitattu 21.5.2018].

Ahn, Jungsun - La Ferle, Carrie 2008: Enhancing Recall and Recognition for Brand Names and Body Copy: A Mixed-Language Approach. Journal of Advertising 37(3), 107-117. https://doi. org/10.2753/JOAoo91-3367370308

Ainiala, Terhi 2016a: Names in Society. Carole Hough (toim.): Oxford Handbook of Names and Naming, 371-381. Oxford University Press, Oxford. https://doi.org/10.1093/oxford$\mathrm{hb} / 9780199656431.013 .27$

2016b: Attitudes to street names in Helsinki. Guy Puzey ja Laura Kostanski (toim.): Names and naming: People, places, perceptions and power, 106-119. Multilingual Matters, Bristol. https:// doi.org/10.21832/9781783094929-010

Ainiala, Terhi - Saarelma, Minna - SJöblom, Paula 2008: Nimistöntutkimuksen perusteet. Tietolipas 221. Suomalaisen Kirjallisuuden Seura, Helsinki.

Brédart, Serge 2016: Names and Cognitive Psychology. Carole Hough (toim.): The Oxford Handbook of Names and Naming, 476-487. Oxford University Press, Oxford. https://doi.org/10.1093/ oxfordhb/9780199656431.013.57

Brédart, Serge - Valentine, Tim 1998: Descriptiveness and Proper Name Retrieval. Memory 6(2), 199-206. https://doi.org/10.1080/741942072

Burke, Deborah M. - MacKay, Donald G. - Worthley, Joanna S. - Wade, Elizabeth 1991: On the tip of the tongue: What causes word finding failures in young and older adults? Journal of Memory and Language 30(5), 542-579. https://doi.org/10.1016/0749-596X(91)90026-G

Cohen, Gillian - Burke, Deborah M. 1993: Memory for proper names: A review. Memory 1(4), 249263. https://doi.org/10.1080/09658219308258237

Fogler, Kethera A. - James, Lori E. 2007: Charlie Brown versus Snow White: The Effects of Descriptiveness on Young and Older Adults' Retrieval of Proper Names. The Journals of Gerontology Series B: Psychological Sciences and Social Sciences 62(4), 201-207. https://doi.org/10.1093/ geronb/62.4.P201

Fogler, Kethera A. - James, Lori E. - Crandall, Elizabeth A. 2010: How Name Descriptiveness Impacts Proper Name Learning in Young and Older Adults. Aging, Neuropsychology and Cognition 17, 505-518. https://doi.org/10.1080/13825580903477245

Hanley, Richard - Chapman, Eleanor 2008: Partial knowledge in a tip-of-the-tongue state about two- and three-word proper names. Psychonomic Bulletin \& Review 15(1), 156-160. https://doi. org/10.3758/PBR.15.1.156

HANley, Richard - Cohen, Gillian 2008: Memory for people: Faces, names and voices. Cohen, GiLlian ja Conway, Martin A. (toim.): Memory in the Real World, 107-140. 3. painos. Psychology Press, Hove, New York.

HÄMÄLÄINEN, LASSE 2016a: Suomalaisten verkkoyhteisöjen käyttäjänimet. Virittäjä 120, 398-422.

_ 2016b: Nimi, joka muistetaan - hyvän nimen ominaisuudet. Kieliviesti 4/2016, 4-8. 2016c: Aapelin Minigolfin esittely. YouTube 19.12.2016. Saatavilla www.youtube.com/ watch?v=r5GmVvmKUXM [viitattu 21.5.2018].

2017: Aapelin Minigolf: Pelaajayhteisön ja sen kulttuurin vaiheita. Pelitutkimuksen vuosikirja $2017,49-59$.

2018 (tulossa): Level Names in an Online Virtual Minigolf Game. Onomastica Uralica. Hyväksytty julkaistavaksi.

Kalakoski, Virpi - SaAriluoma, Pertti 2001: Taxi drivers' exceptional memory of street names. Memory \& Cognition 29(4), 634-638. https://doi.org/10.3758/BFo3200464

Lowrey, Tina M. - Shrum, L. J. - Dubitsky, Tony M. 2003: The Relation Between Brand-name Linguistic Characteristics and Brand-name Memory. Journal of Advertising 32(3), 7-17. https://doi. org/10.1080/00913367.2003.10639137 
Luna, David - Carnevale, Marina - Lerman, Dawn 2013: Does brand spelling influence memory? The case of auditorily presented brand names. Journal of Consumer Psychology 23(1), 36-48. https://doi.org/10.1016/j.jcps.2012.02.003

McWeeny, Kathryn H. - Andrew W. Young - Dennis C. Hay - Andrew W. Ellis 1987: Putting names to faces. British Journal of Psychology 78(2), 143-149. https://doi.org/10.1111/j.2044-8295.1987. tbo2235.X

Müller, Horst M. 2010: Neurolinguistic Findings on the Language Lexicon: The Special Role of Proper Names. Chinese Journal of Physiology 53(6), 351-358. https://doi.org/10.4077/CJP.2010. AMMo32

NÄrhi, Eeva Maria 1999: Ratamestareita, Pasuunoita, Orpaanportaita - Aihepiirien käyttö nimistönsuunnittelussa. JYRKi LeHIKOINEN (toim.): Helsingin kadunnimet 3. Helsingfors gatunamn 3. Helsinki, Helsingin kaupungin nimistötoimikunta.

Schwartz, Bennett L. 2014: Memory for People: Integration of Face, Voice, Name, and Biographical Information. Timothy J. Perfect ja D. Stephen Lindsay (toim.): The SAGE Handbook of Applied Memory, 3-19. SAGE Publications Ltd, Los Angeles.

SJöвlom, PAUla 2006: Toiminimen toimenkuva: suomalaisen yritysnimistön rakenne ja funktiot. Suomalaisen Kirjallisuuden Seura, Helsinki.

Sjöblom, Paula 2016: Commercial names. Carole Hough (toim.): Oxford Handbook of Names and Naming, 453-464. Oxford University Press, Oxford. https://doi.org/10.1093/oxford$\mathrm{hb} / 9780199656431.013 .56$

TAATELI.COM 2018: Minigolfin ratalista. Saatavilla http://www.taateli.com/index.php?s=ratalista\&lista $=$ minigolf [viitattu 7.6.2018].

Usunier, Jean-Claude - Shaner, JANEt 2002: Using linguistics for creating better international brand names. Journal of Marketing Communications 8(4), 211-228. https://doi. org/10.1080/1352726021014600o

Vehkalahti, Kimmo 2014: Kyselytutkimuksen mittarit ja menetelmät. Finn Lectura, Helsinki.

White, John S. 1970: Tables of Normal Percentile Points. Journal of the American Statistical Association 65, 635-638. https://doi.org/10.1080/01621459.1970.10481112

Wippich, Werner 1995: Namengedächtnis und Namenlernen. Ernst Eichler, Gerold Hilty, HeinRich Löffler, Hugo Steger ja Ladislav Zgusta (toim.): Namenforschung. Ein internationales Handbuch zur Onomastik. Name studies. An international handbook of onomastics. Les noms propres. Manuel international d’onomastique, 489-493. Walter de Gruyter, Berlin.

\section{LASSE HÄMÄLÄINEN: Candle in the wind: An empirical study on the memorability of names in virtual miniature golf}

Previous studies have shown that proper names are more difficult to remember than other words. However, very few studies have focused on the memorability of names, which refers to what kinds of names are remembered well or poorly. This article examines the memorability of names with empirical test data. 33 Minigolf players, a video game found in the Finnish online gaming community Playforia, participated in two experiments which tested how well they can remember the names of levels in the game. A qualitative analysis of the test results revealed several factors that influence the memorability of names. Five factors were chosen for a more precise quantitative analysis: the principle of naming, the language of a name, the length of a name, a level belonging to a so-called level series, and the importance of a level. A quantitative analysis shows that all five of these factors have a statistically significant influence on the results. This means that the memorability of a name consists of several factors. 
Liite 1. Lisämateriaalia muistikokeiden tuloksista

Olen koonnut artikkelille 31-sivuisen liitetiedoston, joka on saatavilla avoimesti verkossa. Liite sisältää kuvan ja lyhyen kommentin jokaisesta muistikokeissa esiintyneestä radasta sekä kvantitatiivisen analyysin tarkat tulokset. Liitteen lukeminen ei ole välttämätöntä artikkelin sisällön ymmärtämiseksi, mutta se voi tarjota vahvistusta artikkelissa esitetyille väitteille sekä kiinnostavia lisähuomioita koetuloksiin liittyen.

Liitetiedostoon voi tutustua osoitteessa www.researchgate.net/publication/325713389 (viitattu 12.6.2018). Kuvat muistikokeissa esiintyneistä radoista ovat nähtävissä suurempikokoisina sähköisessä kuva-albumissa osoitteessa www.imgur.com/a/oc3fm.

Lasse Hämäläinen

lasse.j.hamalainen@helsinki.fi

Helsingin yliopisto

00014 Helsingin yliopisto 